\title{
Catalytic Chemical Vapor Deposition of Methane to Carbon Nanotubes: Copper Promoted Effect of Ni/MgO Catalysts
}

\author{
Wen Yang, Yanyan Feng, and Wei Chu \\ Department of Chemical Engineering, Sichuan University, Chengdu 610065, China \\ Correspondence should be addressed to Wei Chu; chu1965chengdu@163.com
}

Received 8 January 2014; Accepted 21 May 2014; Published 4 June 2014

Academic Editor: Valery Khabashesku

Copyright ( 2014 Wen Yang et al. This is an open access article distributed under the Creative Commons Attribution License, which permits unrestricted use, distribution, and reproduction in any medium, provided the original work is properly cited.

\begin{abstract}
The $\mathrm{Ni} / \mathrm{MgO}$ and $\mathrm{Ni}-\mathrm{Cu} / \mathrm{MgO}$ catalysts were prepared by sol-gel method and used as the catalysts for synthesis of carbon nanotubes by thermal chemical vapor deposition. The effect of $\mathrm{Cu}$ on the carbon yield and structure was investigated, and the effects of calcination temperature and reaction temperature were also investigated. The catalysts and synthesized carbon materials were characterized by temperature programmed reduction (TPR), thermogravimetric analysis (TGA), and scanning electron microscopy (SEM). Results showed that the addition of $\mathrm{Cu}$ promoted the reduction of nickel species, subsequently improving the growth and yield of CNTs. Meanwhile, CNTs were synthesized by the $\mathrm{Ni} / \mathrm{MgO}$ and $\mathrm{Ni}-\mathrm{Cu} / \mathrm{MgO}$ catalysts with various calcination temperatures and reaction temperatures, and results suggested that the obtained $\mathrm{CNTs}$ on $\mathrm{Ni}-\mathrm{Cu} / \mathrm{MgO}$ catalyst with the calcination temperature of $500^{\circ} \mathrm{C}$ and the reaction temperature of $650^{\circ} \mathrm{C}$ were of the greatest yield and quantity of $927 \%$.
\end{abstract}

\section{Introduction}

Due to the unique mechanical [1], chemical, electrical, magnetic, thermal, and other properties, carbon nanotubes (CNTs) have attracted many interests [1-3] and have been applied in various fields, such as electronics, medicine, and catalysis $[3,4]$. Therefore, intense research efforts have been undertaken to produce CNTs at a reasonable cost. Currently, CNTs are mainly prepared by arc discharge $[5,6]$, laser evaporation [7], and chemical vapor deposition (CVD) methods [3, 8-11], among which the CVD method has been the most widely used method, appearing to be the most promising way to the large scale production of high purity CNTs at the lowest cost using the cheapest apparatus operating at a relatively low temperature [2].

In the CVD method, the quality and yield of CNTs are closely related to the used catalysts, reaction conditions, and the carbon source. In CVD synthesis of CNTs, Fe [12], Co $[11,12]$, and $\mathrm{Ni}[1,8,13,14]$ as the active component on the oxides, such as $\mathrm{Al}_{2} \mathrm{O}_{3}[1], \mathrm{SiO}_{2}[15,16]$, and $\mathrm{MgO}$ $[8,9,12,14,17]$, or as an organometallic catalyst $[16,18]$, is usually used as catalyst. In addition, methane $[9,12,14]$, acetylene [2], and other hydrocarbons compounds [10] or $\mathrm{CO}, \mathrm{CO}_{2}$ [4], ethanol [17], and the like [11, 16, 19] are usually used as the carbon source.

According to the literature $[14,20,21]$, with preparing CNTs by the $\mathrm{Ni} / \mathrm{MgO}$ catalyst, the $\mathrm{NiO}$ and $\mathrm{MgO}$ solid solution structure was easily formed and then reduced to very fine nickel particles when subjected to high temperature, subsequently producing the CNTs with narrow diameter, thin wall, and good quality. Since few Ni particles were reduced from the solid solution structure, only a small amount of CNTs was produced. Studies showed that the introduction of suitable additive in $\mathrm{Ni} / \mathrm{MgO}$ catalyst can not only increase the amount of reduced $\mathrm{Ni}$ particles, but also prevent the formation of amorphous carbon and prolong the stability of the catalyst [17]. For $50 \% \mathrm{Ni} / \mathrm{MgO}$ catalyst (wt.\%), the optimum content of copper $(\mathrm{Cu})$ was $4 \sim 6 \%$ to obtain high yield and quality of CNTs. In this study, the CNTs were synthesized using $\mathrm{Ni} / \mathrm{MgO}$ and $\mathrm{Ni}-\mathrm{Cu} / \mathrm{MgO}$ catalysts, and the effect of $\mathrm{Cu}$ on the carbon yield and structure were investigated, and the effects of calcination temperature and reaction temperature were also investigated. 
TABLE 1: Prepared conditions of the catalysts.

\begin{tabular}{lcccc}
\hline Catalyst & $\mathrm{Ni}($ wt.\%) & $\mathrm{Cu}($ wt.\%) & $\begin{array}{c}\text { Calcination } \\
\text { temperature } \\
\left({ }^{\circ} \mathrm{C}\right)\end{array}$ & $\begin{array}{c}\text { Reaction } \\
\text { temperature } \\
\left({ }^{\circ} \mathrm{C}\right)\end{array}$ \\
\hline $\mathrm{Ni} / \mathrm{MgO}$ & 50 & 0 & $400 \sim 500$ & $550 \sim 750$ \\
$\mathrm{Ni}-\mathrm{Cu} / \mathrm{MgO}$ & 50 & 5 & & \\
\hline
\end{tabular}

\section{Experiment}

2.1. Preparation of Catalysts. The catalysts $\mathrm{Ni} / \mathrm{MgO}$ and $\mathrm{Ni}-$ $\mathrm{Cu} / \mathrm{MgO}$ were prepared by sol-gel method, and the prepared conditions of the catalysts were shown in Table 1. $\mathrm{Ni}\left(\mathrm{NO}_{3}\right)_{2} \cdot 6 \mathrm{H}_{2} \mathrm{O}, \mathrm{Cu}\left(\mathrm{NO}_{3}\right)_{2} \cdot 3 \mathrm{H}_{2} \mathrm{O}, \mathrm{Mg}\left(\mathrm{NO}_{3}\right)_{2} \cdot 6 \mathrm{H}_{2} \mathrm{O}$, and citric acid with a stoichiometric ratio were dissolved in deionized water, subsequently stirring and evaporating at $70^{\circ} \mathrm{C}$ until the solution became viscous colloids. Then the catalysts were dried in an oven at $120^{\circ} \mathrm{C}$ for $24 \mathrm{~h}$ and placed in the muffle furnace calcined at $400 \sim 500^{\circ} \mathrm{C}$ for $3 \mathrm{~h}$.

2.2. Experimental Procedure. $100 \mathrm{mg}$ of the catalyst powder was dispersed on a ceramic boat and then placed in a horizontal quartz reactor (inner diameter $=3.5 \mathrm{~cm}$ ) to grow CNTs. Firstly, the catalyst powder was reduced in situ in $\mathrm{H}_{2}$ at $550^{\circ} \mathrm{C}$ for $1 \mathrm{~h}$ and then raised to the reaction temperature of 550 $750^{\circ} \mathrm{C}$. Subsequently, the system was switched to methane of high purity $(50 \mathrm{~mL} / \mathrm{min})$ for $1 \mathrm{~h}$. After the reaction, the as-grown CNTs were cooled to room temperature in $\mathrm{N}_{2}$ atmosphere.

2.3. Characterization. The catalysts and produced CNTs were characterized by means of hydrogen temperatureprogrammed reduction $\left(\mathrm{H}_{2}-\mathrm{TPR}\right)$, scanning electron microscopy (SEM), and thermogravimetric analysis (TGA).

\section{Results and Discussion}

Temperature programmed reduction of $\mathrm{H}_{2}\left(\mathrm{H}_{2}-\mathrm{TPR}\right)$ is usually employed for estimating reducibility of the catalyst. The $\mathrm{H}_{2}$-TPR profiles of $\mathrm{Ni} / \mathrm{MgO}$ with various calcination temperatures were displayed in Figure 1. The catalysts presented two reduction peaks; one centered at $300^{\circ} \mathrm{C}$ and the other broad peak existed at around $645^{\circ} \mathrm{C}$ or so. Most of the nickel species in the catalysts was reduced in the high temperature. With the increase of calcination temperature, the second reduction peak of $\mathrm{Ni} / \mathrm{MgO}$ was shifted to low temperature, while the first reduction peak area increased. When the catalyst was calcined at $500^{\circ} \mathrm{C}$, the two reduction peaks were located at $300^{\circ} \mathrm{C}$ and $644^{\circ} \mathrm{C}$, respectively.

Figure 2 presented $\mathrm{H}_{2}$-TPR profiles of the samples $\mathrm{Ni} / \mathrm{MgO}$ and $\mathrm{Ni}-\mathrm{Cu} / \mathrm{MgO}$ calcined at $500^{\circ} \mathrm{C}$. Compared with $\mathrm{Ni} / \mathrm{MgO}$, the interaction was weaker between $\mathrm{Ni}-\mathrm{Cu} / \mathrm{MgO}$ and nickel species. As seen from Figure 2, $\mathrm{Cu}$ was added to promote the reduction of the nickel species, proved by a significant increase in low-temperature reduction peak area of $\mathrm{H}_{2}$-TPR profile of $\mathrm{Ni}-\mathrm{Cu} / \mathrm{MgO}$. The reduction peaks of $\mathrm{Ni}$ $\mathrm{Cu} / \mathrm{MgO}$ were located at $290^{\circ} \mathrm{C}, 438^{\circ} \mathrm{C}$, and $640^{\circ} \mathrm{C}$, respectively. The decrease of the reduction peaks temperatures can

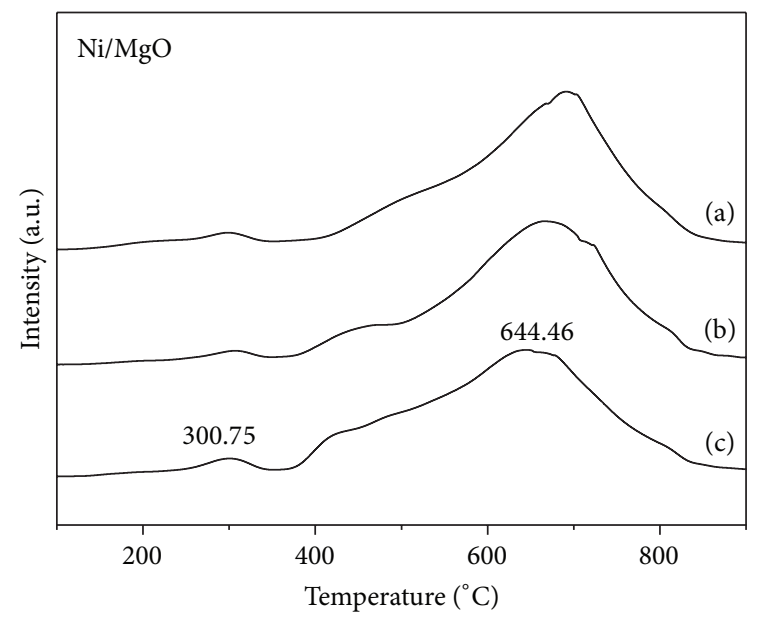

FIGURE 1: $\mathrm{H}_{2}$-TPR profiles of $\mathrm{Ni} / \mathrm{MgO}$ catalysts with various calcination temperatures. (a) $400^{\circ} \mathrm{C}$; (b) $450^{\circ} \mathrm{C}$; and (c) $500^{\circ} \mathrm{C}$.

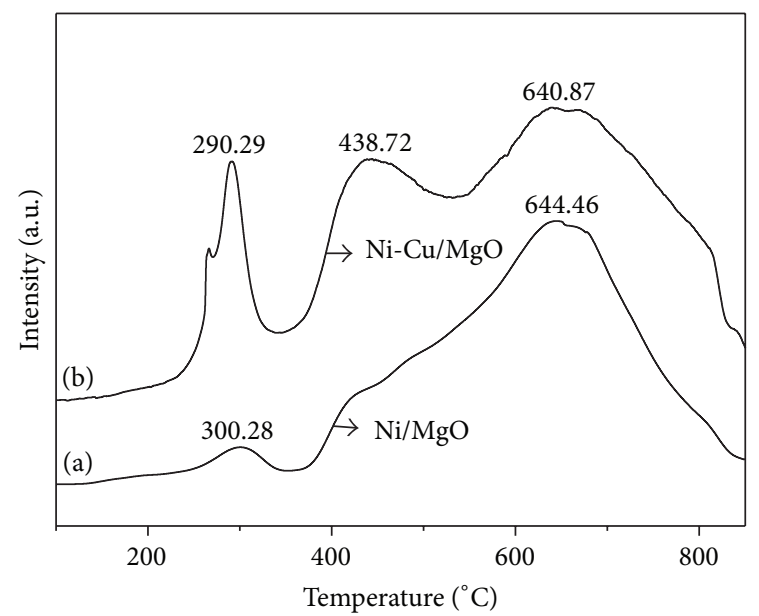

FIGURE 2: $\mathrm{H}_{2}$-TPR profiles of the catalysts (a) $\mathrm{Ni} / \mathrm{MgO}$ and (b) $\mathrm{Ni}$ $\mathrm{Cu} / \mathrm{MgO}$ calcined at $500^{\circ} \mathrm{C}$.

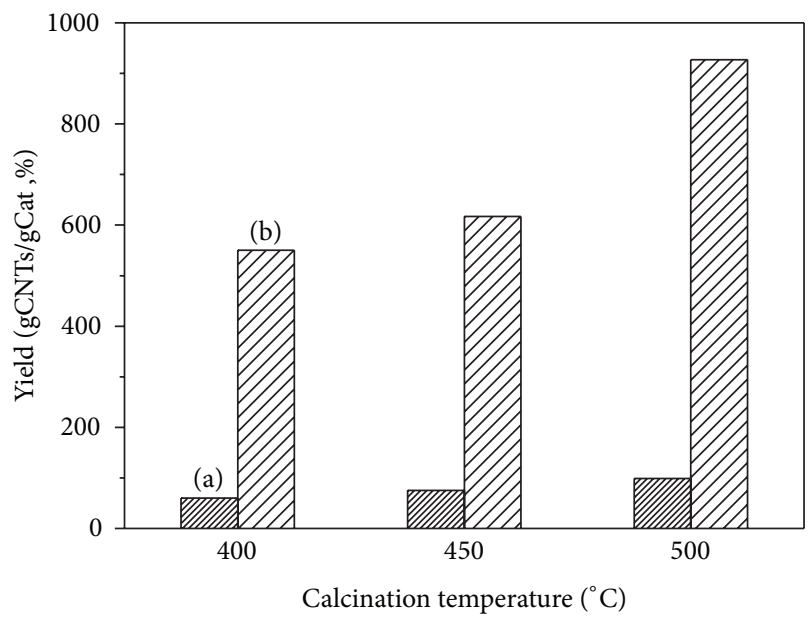

FIGURE 3: Yield of carbon on the catalysts (a) $\mathrm{Ni} / \mathrm{MgO}$ and (b) Ni$\mathrm{Cu} / \mathrm{MgO}$ calcined at different temperatures (reaction temperature at $\left.650^{\circ} \mathrm{C}\right)$. 


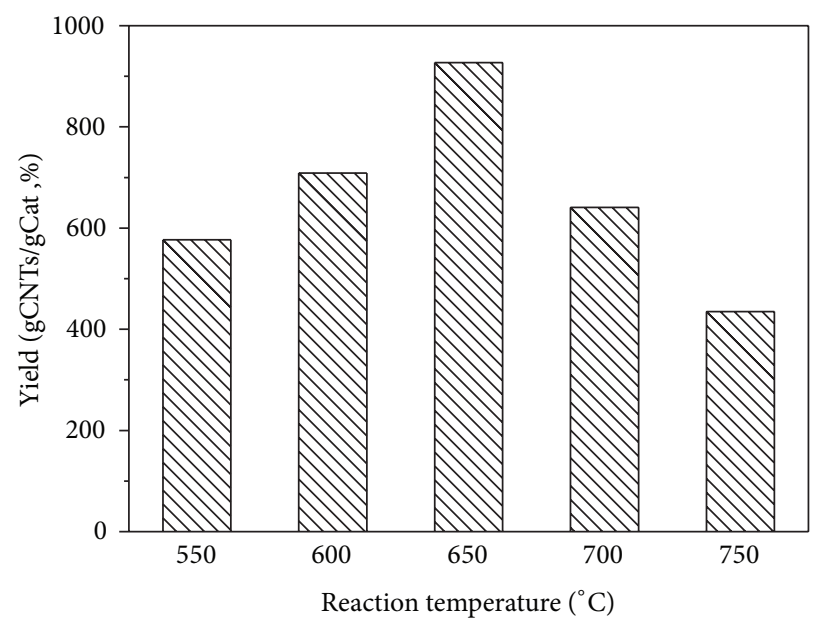

FIGURE 4: Yield of carbon on the catalyst $\mathrm{Ni}-\mathrm{Cu} / \mathrm{MgO}$ calcined at $500^{\circ} \mathrm{C}$ with different reaction temperatures.

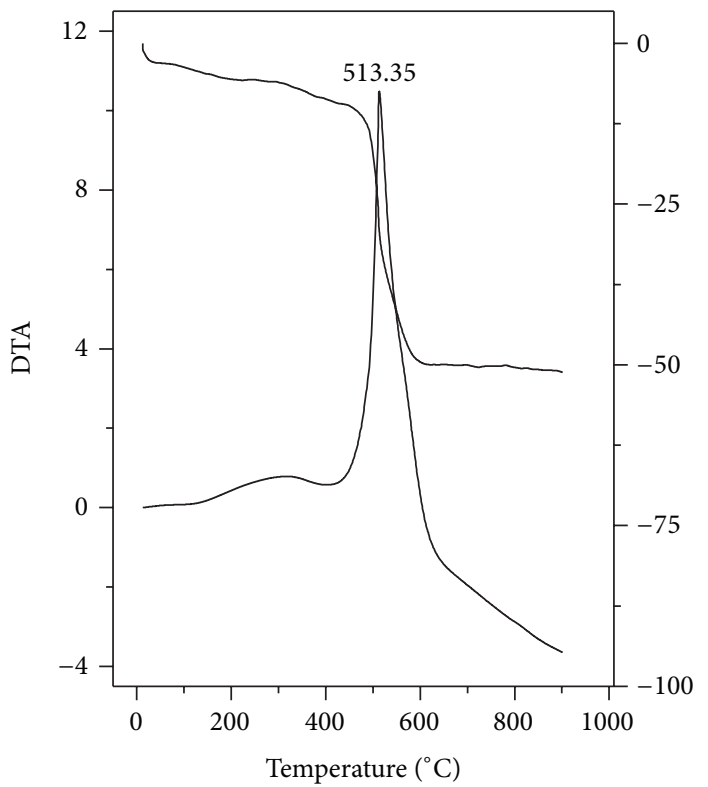

(a)

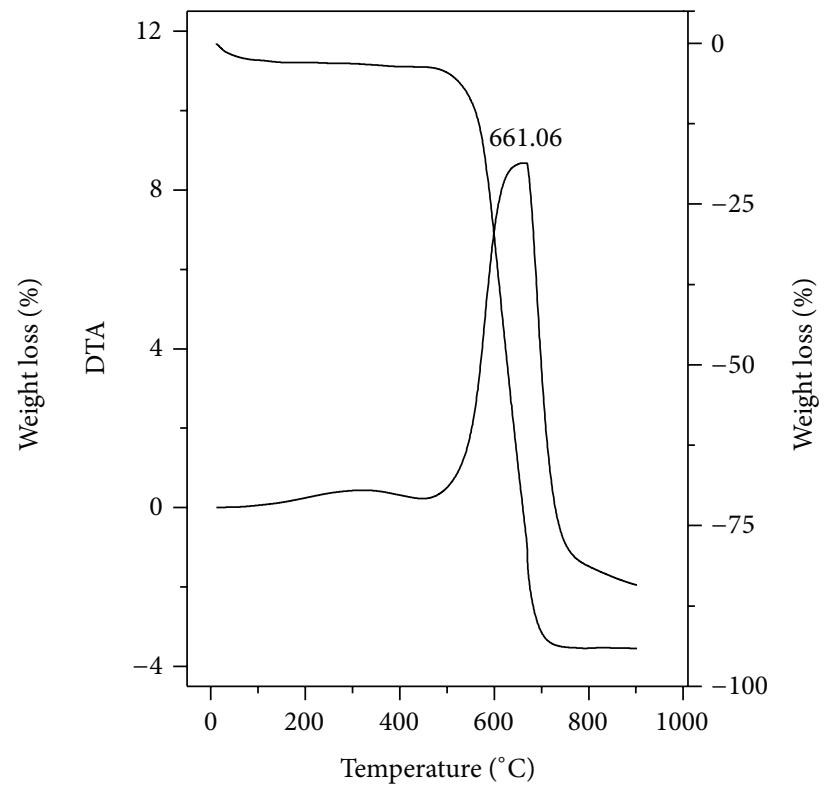

(b)

Figure 5: TG and DTA curves of the obtained products from the catalysts (a) $\mathrm{Ni} / \mathrm{MgO}$ and (b) $\mathrm{Ni}-\mathrm{Cu} / \mathrm{MgO}$ calcined at $500^{\circ} \mathrm{C}$ with reaction temperature $650^{\circ} \mathrm{C}$.

be attributed to the overflow effect of hydrogen caused by $\mathrm{Cu}$, which activated hydrogen molecules, thereby promoting the reduction reaction of hydrogen and nickel species at low temperatures.

Figure 3 showed the yield of carbon materials on the catalysts calcined at different temperatures. Compared to the catalyst $\mathrm{Ni} / \mathrm{MgO}, \mathrm{Ni}-\mathrm{Cu} / \mathrm{MgO}$ had the obvious advantage in the reaction of methane decomposition. It could be noted that the $\mathrm{Ni} / \mathrm{MgO}$ exhibited very poor activity in the decomposition of methane and growth of carbon materials. $\mathrm{Ni} / \mathrm{MgO}$ possessed the highest yield of $99 \%$, while the highest yield for $\mathrm{Ni}-\mathrm{Cu} / \mathrm{MgO}$ was $927 \%$. The $\mathrm{Cu}$ addition into $\mathrm{Ni} / \mathrm{MgO}$ significantly increased the catalytic activity of the catalyst and improved the growth of carbon nanomaterials, which could provide adequate catalytic sites as represented in the $\mathrm{H}_{2}-\mathrm{TPR}$ results shown in Figure 2.

As shown in Figure 4, when the reaction temperature was low, the rate of methane decomposition was limited, thus obtaining few carbon atoms and low CNTs yield. As the reaction temperature increased, the decomposition rate of methane accelerated, and a number of carbon atoms were deposited on the catalyst surface, finally generating CNTs with the high yield. However, when the temperature was too high, the catalyst particles sintered and became large, and then a large amount of carbon deposited on the surface of the catalyst particles, thus lowering the catalyst activity. 


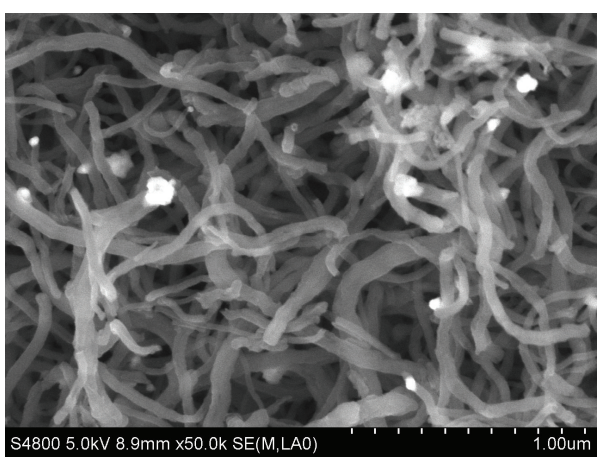

(a)

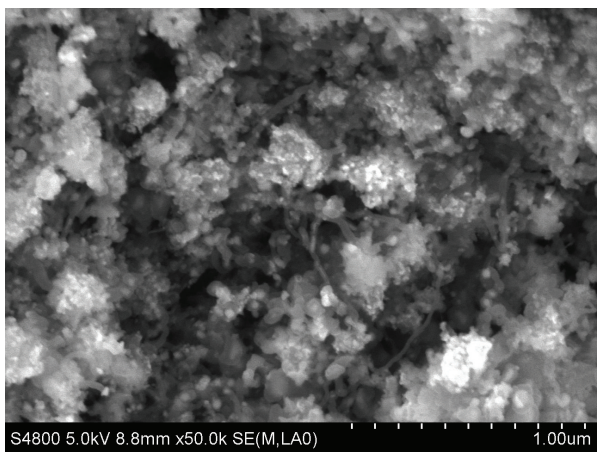

(c)

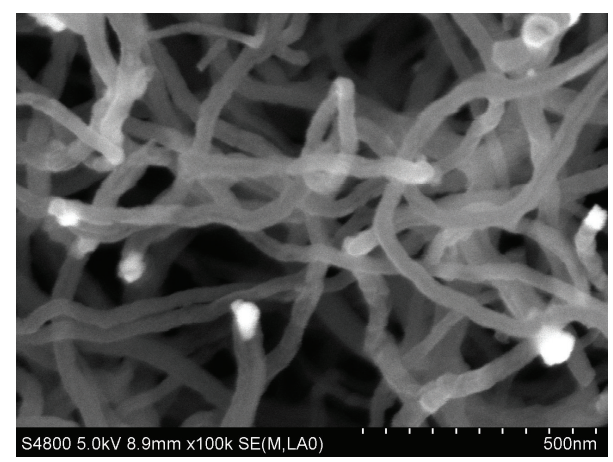

(b)

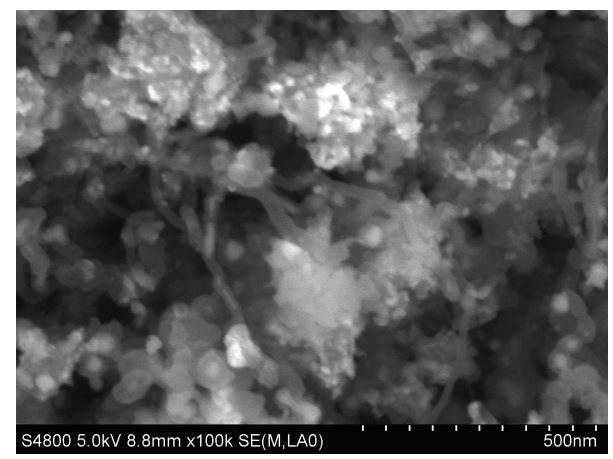

(d)

Figure 6: SEM images of as-produced materials grown on the catalysts (a), (b) $\mathrm{Ni}-\mathrm{Cu} / \mathrm{MgO}$ and (c), (d) $\mathrm{Ni} / \mathrm{MgO}$ calcined at $500^{\circ} \mathrm{C}$ with reaction temperature of $650^{\circ} \mathrm{C}$.

Therefore, in order to obtain the high yield of CNTs, the reaction temperature should be appropriate.

Thermogravimetric analysis (TGA) has been widely used for the reaction selectivity of the catalyst and the crystallinity of the as-produced CNTs. Typically, those losses were attributed to the removal of amorphous carbon $\left(300 \sim 400^{\circ} \mathrm{C}\right)$, CNTs $\left(400 \sim 700^{\circ} \mathrm{C}\right)$, and massive graphite carbon $\left(>700^{\circ} \mathrm{C}\right)$. Figure 5 showed the weight loss of the products during heating in air. Compared with $\mathrm{Ni} / \mathrm{MgO}$, the CNTs prepared by $\mathrm{Ni}-\mathrm{Cu} / \mathrm{MgO}$ possessed most of the weight loss (94\%) at $400 \sim 700^{\circ} \mathrm{C}$, indicating high purity of the CNTs. However, less weight loss was associated with CNTs for the products grown on $\mathrm{Ni} / \mathrm{MgO}$, only about $51 \%$. It was found that the $\mathrm{Ni}$ $\mathrm{Cu} / \mathrm{MgO}$ catalyst possessed the highest selectivity toward the growth of CNTs, consistent with the results of SEM images shown in Figure 6.

\section{Conclusions}

The synthesis of CNTs using $\mathrm{Ni} / \mathrm{MgO}$ and $\mathrm{Ni}-\mathrm{Cu} / \mathrm{MgO}$ catalysts was studied, and the effect of $\mathrm{Cu}$ addition on the carbon yield and structure were investigated. The addition of $\mathrm{Cu}$ significantly increased the yield of CNTs. TPR results showed that the $\mathrm{Cu}$ addition was effective to improve the reduction of the active nickel component and the catalytic performance of the catalyst. The obtained CNTs on Ni$\mathrm{Cu} / \mathrm{MgO}$ catalyst calcined at $500^{\circ} \mathrm{C}$ with reaction temperature of $650^{\circ} \mathrm{C}$ were of the greatest yield and quantity.

\section{Conflict of Interests}

The authors declare that there is no conflict of interests regarding the publication of this paper.

\section{Acknowledgment}

Financial support has been provided by the National Basic Research Program of China (973 Program, 2011CB201202) of Ministry of Science and Technology of China (MOST).

\section{References}

[1] I. Abdullahi, N. Sakulchaicharoen, and J. E. Herrera, "A mechanistic study on the growth of multi-walled carbon nanotubes by methane decomposition over nickel-alumina catalyst," Diamond and Related Materials, vol. 23, pp. 76-82, 2012.

[2] X. Yang, C. Shi, E. Liu et al., "Low-temperature synthesis of multi-walled carbon nanotubes over $\mathrm{Cu}$ catalyst," Materials Letters, vol. 72, pp. 164-167, 2012.

[3] M. Ran, Y. Liu, W. Chu, Z. Liu, and A. Borgna, "High dispersion of $\mathrm{Ru}$ nanoparticles supported on carbon nanotubes synthesized by water-assisted chemical vapor deposition for cellobiose conversion," Catalysis Communications, vol. 27, pp. 69-72, 2012.

[4] W. Chu, M. Ran, X. Zhang et al., "Remarkable carbon dioxide catalytic capture (CDCC) leading to solid-form carbon material via a new CVD integrated process (CVD-IP): an alternative route for $\mathrm{CO}_{2}$ sequestration," Journal of Energy Chemistry, vol. 22, no. 1, pp. 136-144, 2013. 
[5] M. S. Jeong, J. H. Han, and Y. C. Choi, "Influence of the purification process on the semiconducting content of single-walled carbon nanotubes synthesized by arc discharge," Carbon, vol. 57, pp. 338-345, 2013.

[6] K. Vasu, K. Pramoda, K. Moses, A. Govindaraj, and C. N. R. Rao, "Single-walled nanohorns and other nanocarbons generated by submerged arc discharge between carbon electrodes in liquid argon and other media," Materials Research Express, vol. 1, no. 1, Article ID 015001, 2013.

[7] A. Jedrzejewska, A. Bachmatiuk, I. Ibrahim et al., "A systematic and comparative study of binary metal catalysts for carbon nanotube fabrication using CVD and laser evaporation," Fullerenes Nanotubes and Carbon Nanostructures, vol. 21, no. 4, pp. 273285, 2013.

[8] M. Ran, W. Sun, Y. Liu, W. Chu, and C. Jiang, "Functionalization of multi-walled carbon nanotubes using water-assisted chemical vapor deposition," Journal of Solid State Chemistry, vol. 197, pp. 517-522, 2013.

[9] Y. Jia, P.-Y. Wu, F. Fang, S.-S. Zhou, and D.-Y. Peng, "Synthesis and characterization of unbranched and branched multi-walled carbon nanotubes using $\mathrm{Cu}$ as catalyst," Solid State Sciences, vol. 18, pp. 71-77, 2013.

[10] R. K. Sahoo, V. Daramalla, and C. Jacob, "Multiwall and bamboo-like carbon nanotube growth by CVD using a semimetal as a catalyst," Materials Science and Engineering B: Solid-State Materials for Advanced Technology, vol. 177, no. 1, pp. 79-85, 2012.

[11] W. Yang, W. J. Sun, W. Chu, C. F. Jiang, and J. Wen, "Synthesis of carbon nanotubes using scrap tyre rubber as carbon source," Chinese Chemical Letters, vol. 23, no. 3, pp. 363-366, 2012.

[12] J. Wen, W. Chu, C. Jiang, and D. Tong, "Growth of carbon nanotubes on the novel $\mathrm{FeCo}-\mathrm{Al}_{2} \mathrm{O}_{3}$ catalyst prepared by ultrasonic coprecipitation," Journal of Natural Gas Chemistry, vol. 19, no. 2, pp. 156-160, 2010.

[13] M. Borghei, R. Karimzadeh, A. Rashidi, and N. Izadi, "Kinetics of methane decomposition to COx-free hydrogen and carbon nanofiber over $\mathrm{Ni}-\mathrm{Cu} / \mathrm{MgO}$ catalyst," International Journal of Hydrogen Energy, vol. 35, no. 17, pp. 9479-9488, 2010.

[14] W. Yang, W. Chu, C. Jiang, J. Wen, and W. Sun, "Cerium oxide promoted $\mathrm{Ni} / \mathrm{MgO}$ catalyst for the synthesis of multi-walled carbon nanotubes," Chinese Journal of Catalysis, vol. 32, no. 8, pp. 1323-1328, 2011.

[15] E. J. Cabrera, R. Amade, L. Jaller, E. Pascual, and E. Bertran, "Template growth of vertically aligned carbon nanotubes using self-assembled monolayers of $\mathrm{SiO}_{2}$ particles by LangmuirBlodgett technique," Journal of Nanoparticle Research, vol. 16, pp. 1-7, 2014.

[16] S. Liu, Y. Zhang, Y. Lin, Z. Zhao, and Q. Li, “Tailoring the structure and nitrogen content of nitrogen-doped carbon nanotubes by water-assisted growth," Carbon, vol. 69, pp. 247$254,2013$.

[17] E. Borowiak-Palen and M. H. Rümmeli, "Activated Cu catalysts for alcohol CVD synthesized non-magnetic bamboo-like carbon nanotubes and branched bamboo-like carbon nanotubes," Superlattices and Microstructures, vol. 46, no. 1-2, pp. 374-378, 2009.

[18] M. Lubej and I. Plazl, "Theoretical and experimental study of iron catalyst preparation by chemical vapor deposition of ferrocene in air," Chemical Engineering Journal, vol. 242, pp. 306312, 2014.
[19] G. Keru, P. G. Ndungu, and V. O. Nyamori, "Nitrogendoped carbon nanotubes synthesised by pyrolysis of (4$\{[$ (pyridine-4-yl) methylidene] amino\} phenyl) ferrocene," Journal of Nanomaterials, vol. 2013, Article ID 750318, 7 pages, 2013.

[20] Y. Li, X. B. Zhang, X. Y. Tao et al., "Mass production of high-quality multi-walled carbon nanotube bundles on a Ni/Mo/MgO catalyst," Carbon, vol. 43, no. 2, pp. 295-301, 2005.

[21] L.-P. Zhou, K. Ohta, K. Kuroda et al., "Catalytic functions of $\mathrm{Mo} / \mathrm{Ni} / \mathrm{MgO}$ in the synthesis of thin carbon nanotubes," Journal of Physical Chemistry B, vol. 109, no. 10, pp. 4439-4447, 2005. 

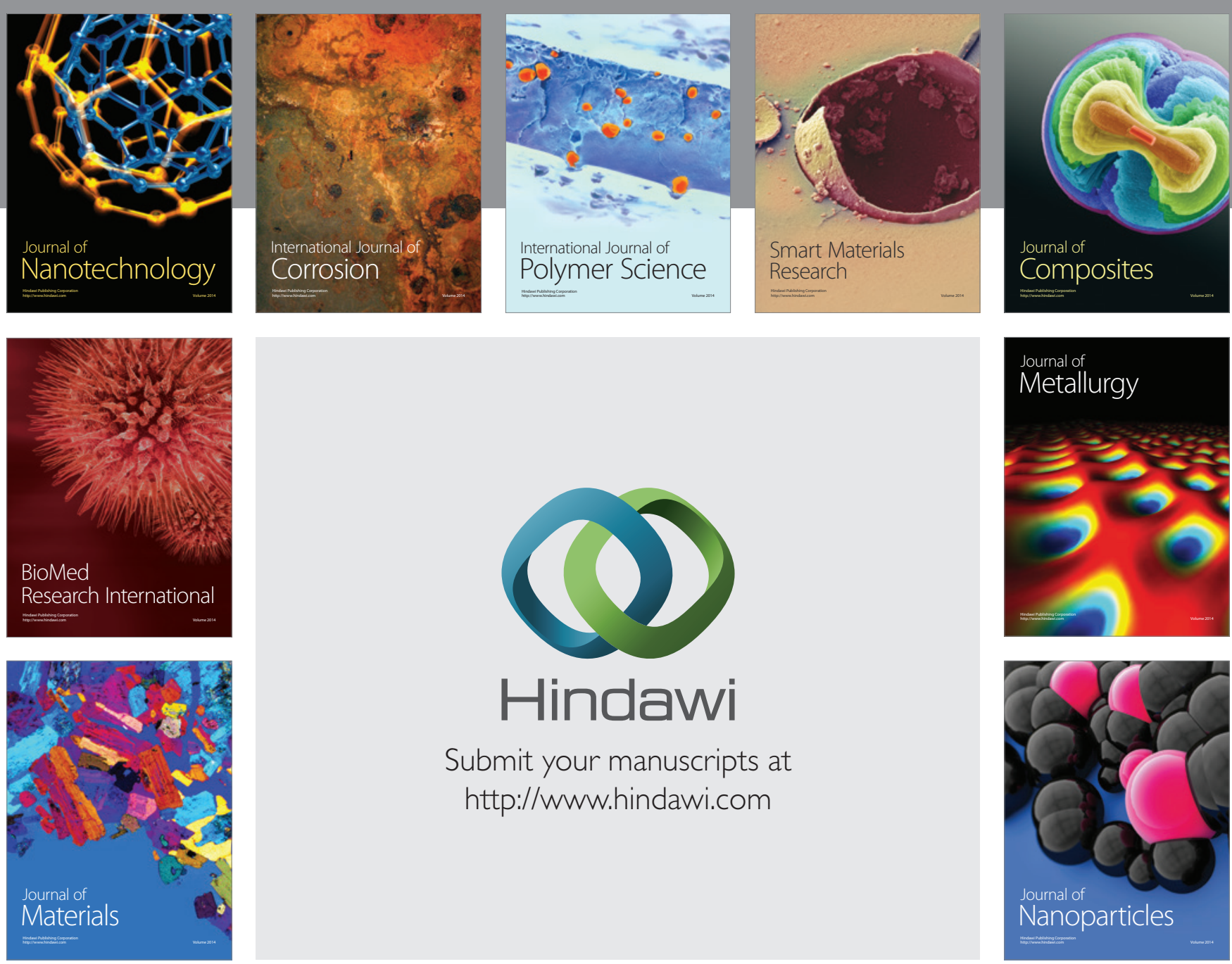

Submit your manuscripts at http://www.hindawi.com
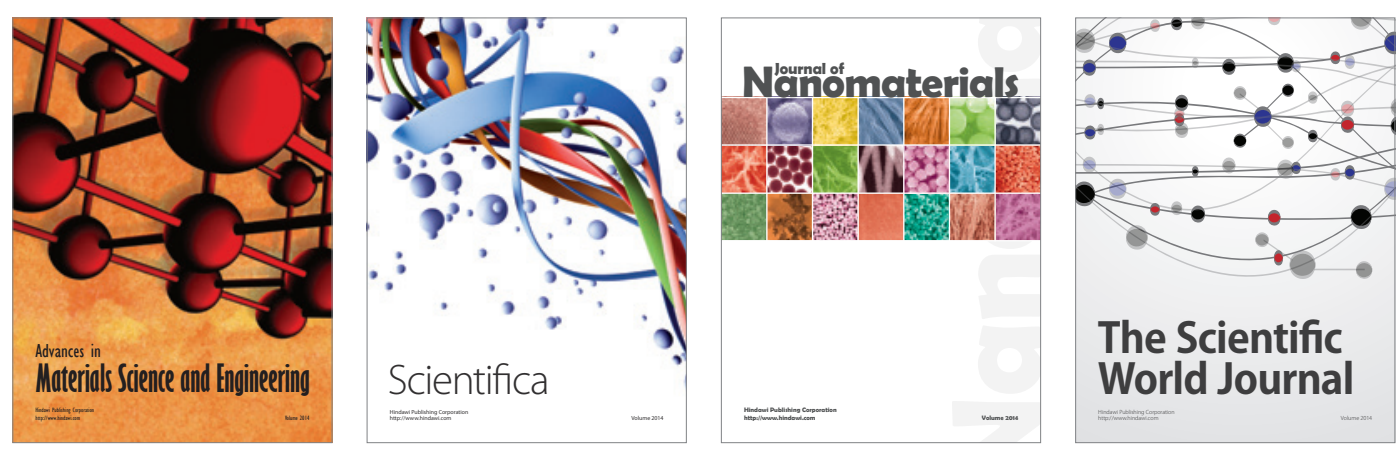

\section{The Scientific World Journal}
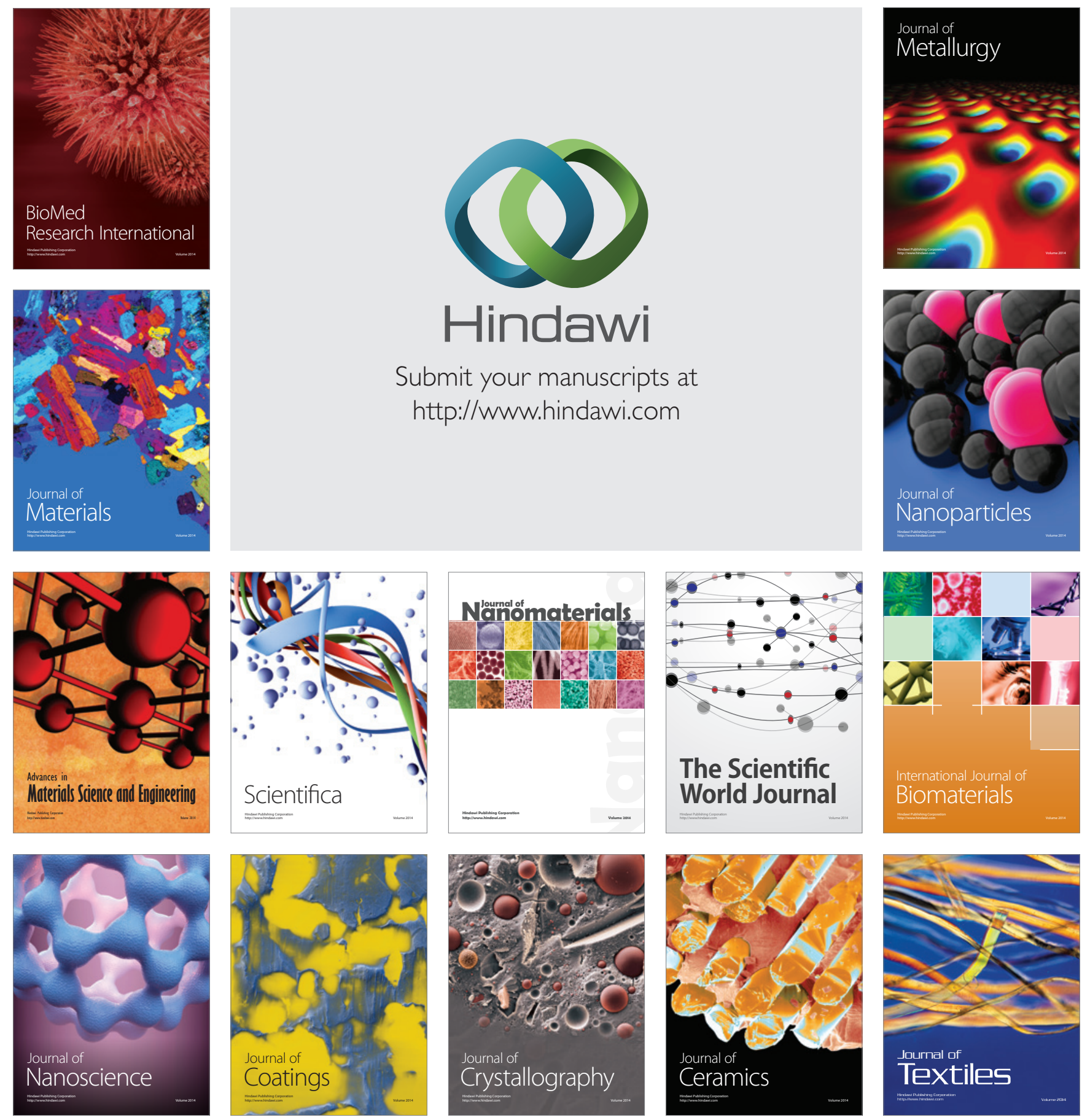